DOMINIK IWEN

Polish Navy, Gdynia, Poland

\title{
HORIZONTAL ACCURACY ISSUES DURING MBES SURVEYS
}

\begin{abstract}
High-resolution Multibeam Echosounder shallow water surveys should not be performed with DGPS (Differential Global Positioning System), especially where feature detection is a priority. Despite the fact that International Hydrographic Organization most demanding Special Order Specification allows for 2 meters horizontal positioning level, it poorly interacts with horizontal centimetric level nadir footprint, causing degradation of bathymetric data.
\end{abstract}

\section{Keywords:}

Multibeam Echosounder, bathymetric survey.

\section{INTRODUCTION}

The availability of Differential GPS since 1994 in Polish Sea Area allows hydrographers to meet IHO Special Order Specifications concerning Total Positioning Uncertainty (THU) during MBES bathymetric surveys [S-44, 2006].

At present, despite over 20 years of constant development of various systems of the depth measuring, the standards of horizontal positioning have not become more restrict. As a result, hydrographers pay more attention to acquiring accurate and reliable vertical data. Centimetric level range accuracies of MBES and other Swath systems combined with precise Inertial Measurement Units, sound velocity sensors, tide gauges, etc., results in reducing Total Vertical Uncenternity (TVU) of the collected data. In my view, horizontal accuracy impact on the overall 
bathymetric data quality acquired with precise high-resolution MBES is frequently neglected or even ignored.

\section{HORIZONTAL ACCURACY AND BATHYMETRIC SURVEYS}

IHO Special Order Specification, which still allows for a maximum THU of $2 \mathrm{~m}$ at a $95 \%$ confidence level accepts the use of DGPS positioning. Data collected with such accuracy is fully adequate for major safety purposes of sea cartography.

However, technical development in multibeam echosounders in recent years resulted in centimetric accuracy and single beam resolution below one degree (Fig. 1). Such precise data is incomparable with above a meter THU offered by DGPS. This leads to 'conscious' deterioration of bathymetric data in shallow water surveys [Brissette, 2012] and among other things my effect inaccurate estimation of dredging volume [Elhattab, 2016].

\begin{tabular}{|c|c|}
\hline $\begin{array}{c}\text { Transducer range } \\
{[\mathrm{m}]}\end{array}$ & $\begin{array}{c}\text { Footprint } \\
{[\mathrm{m}]}\end{array}$ \\
\hline 10 & 0.17 \\
\hline 20 & 0.35 \\
\hline 50 & 0.87 \\
\hline 100 & 1.75 \\
\hline
\end{tabular}

Fig. 1. Footprint as a function of depth (opening beam angle $1^{\circ} \mathrm{x} 1^{\circ}$ )

\section{MBES CALIBRATION}

MBES is a part of a sophisticated system designed to acquire bathymetric data that is next processed to produce Digital Terrain Model (DTM) of sea bottom. To make the system work properly, with the desired accuracy and reliability, a set 
of sensors is to be connected. Apart from combining IMU, SBES, MBES positioning systems, their precise position in ship reference frame must be defined. To achieve that, geodetic measurements are conducted and the results are entered into the database of a bathymetric system controlling software. The problem of entering offsets remains when movable elements such as MBES transducer head is lowered from the deck [Felski et al. 2015; Howlett, 2017].

According to regulations and recommendations contained in IHO Manual of Hydrography [Manual, 2011], each time before starting a multibeam echosounder survey, it is necessary to perform a patch test. The reason that a calibration must be executed is the calculation of the present angular mounting offsets of transducer head towards the axis of a reference unit motion. This procedure consists of sailing a series survey lines in a specified scheme. Selection of suitable profiles over an applicable bottom allows to extract roll, pitch and yaw components of the transducer head misalignment. Finally, new offsets are computed by calibration software.

\section{THE IMPACT OF POSITIONING ERRORS ON CALIBRATION RESULTS}

A calibration of EM 3002D was performed on Polish Navy Survey Vessel ORP 'Arctowski' in December 2015. The ship is equipped with Kongsberg a double head system mounted solidly in a blister. Positioning and motion data was supported by SEAPATH 300 with MRU 5. All patch test profiles were conducted twice, at the same speed. Firstly, GPS observations were altered with differential data received from DGPS station ROZEWIE. In the second pass, Trimble VRSNet service supported phase RTK correction ${ }^{1}$. After acquiring the bathymetric data, an analysis was done with the use of QPS postprocessing software (QINSy Validator and QIMERA). Based on computation results, the pitch offsets considerably differed in both runs (see Fig. 2).

Bad calibration results in the diminished accuracy of both position and depth measurements. The error rises with the range of the transducer. As far as wrong values of 'roll' parameters are easy to spot because of the odd looking

${ }^{1}$ VRS Net provides instant access to real-time kinematic (RTK) corrections utilizing a network of permanent (fixed) continuously operating reference stations. 
shape of bottom contours, 'pitch' errors are much harder to detect. The reasons are equal along track errors for the whole profile. This, however, can maximize the horizontal positioning errors to a level that is unsuitable for IHO S-44 Standards (see Fig. 3).

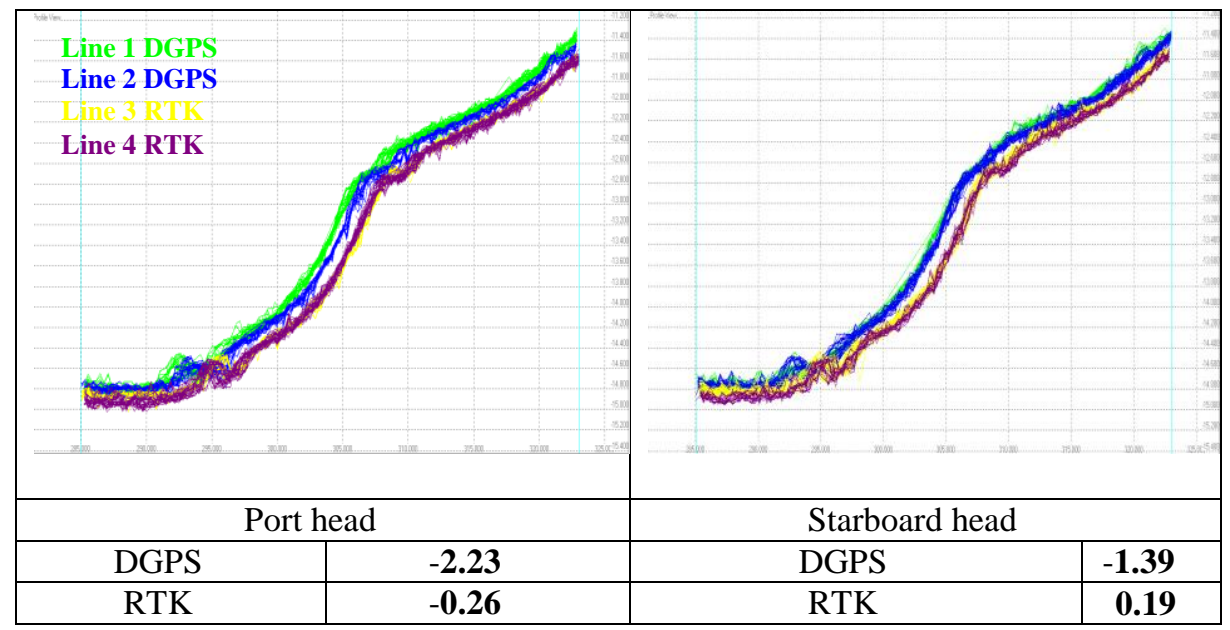

Fig. 2. Comparison of patch test 'pitch' results

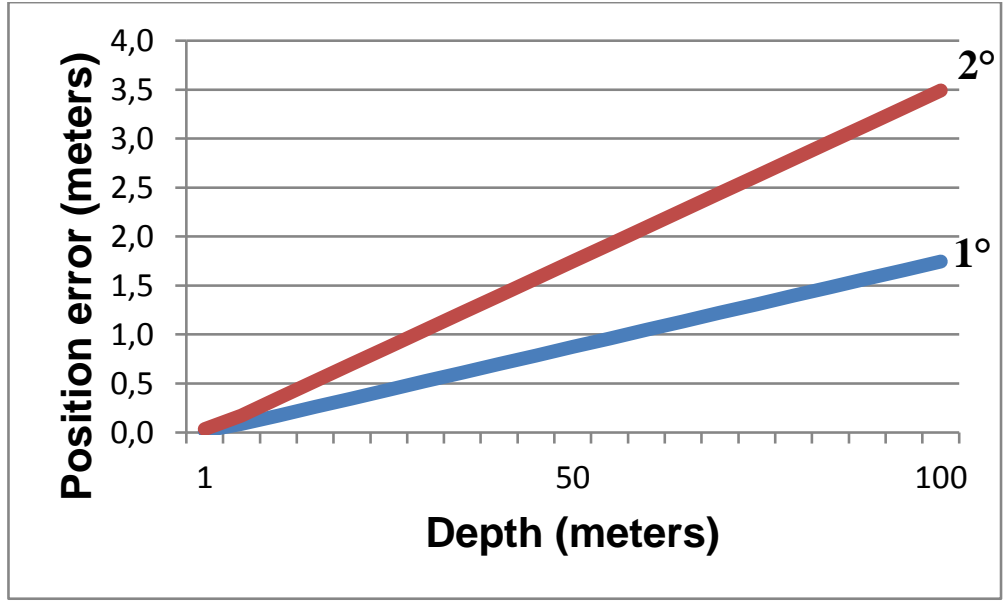

Fig. 3. Effect of 'pitch' errors on the position accuracy

Detection and verification of sea bottom object is an important part of the bathymetric survey. Every detection that meets the IHO standards needs to be 
pointed and verified. The data concerning target shape, dimensions and the most important under keel clearance has to be collected. To do that MBES as well towed side scan sonar are used. Unfortunately, there are numerous factors that determine the ability to use towed equipment like weather condition, swell or fishing nets. Also, the problem with the positioning of submerge sensors is a factor. The best solution is the use of USBL underwater acoustic positioning systems. All things considered, most often data collected with MBES is the primary source of sea bottom object information. It is performed by sailing a number of survey lines over and by the object with low speed in order to acquire enough data to characterize the target.

In the Figure 4 an example of bathymetric data from 2 survey lines sailed over a German World War Two torpedo in Puck Bay is presented.

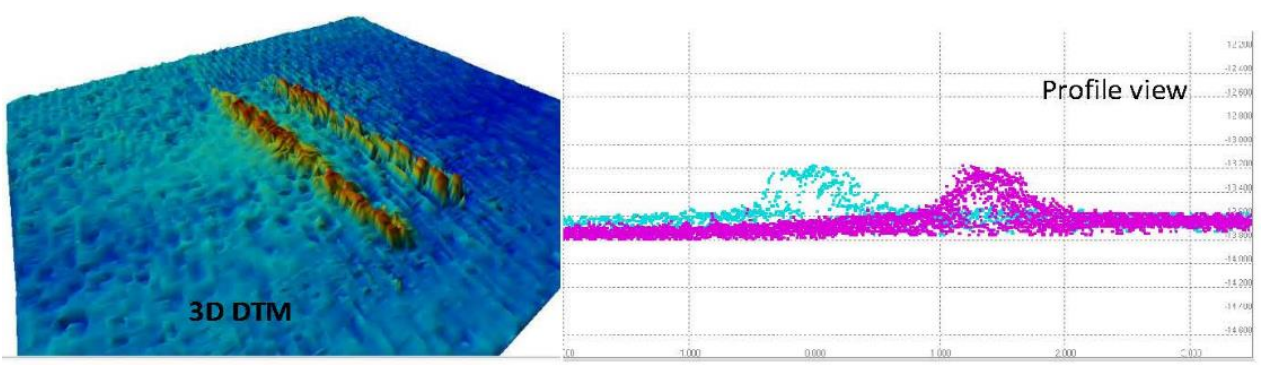

Fig. 4. Presentation of survey data from 2 profiles [QPS Qloud software]

The horizontal position of the torpedo on the first profile differs about $1.5 \mathrm{~m}$ from it's position on the second one while using DGPS. Such data can lead to poor results and bad interpretation when measuring the dimension of the target or as in this case, an erroneous observation of two torpedoes instead of one. In consequence, sometimes one survey line gives more reliable information than a few. There is also need to use other sources like side scan sonar or even ROV to characterize the bottom object and this requires significantly more time and equipment.

\section{CONCLUSIONS}

Still, the main task of IHO S-44 is to determine the attributes of a bathymetric survey used mostly for the cartography and the production and update of nautical charts. In other words, IHO S-44 aims at ensuring the safety of navigation. To achieve it, the Special Order THU of 2 meters is in most cases sufficient. 
However, the implementation these assignments require precise calibration results of MBES, which cannot be precisely handled without reliable centimeter level horizontal positioning systems like RTK.

Additionally, the IHO minimal standards do not 'prohibit' institutions to demand stricter constrains for the bathymetric survey in dredging operations. Precise bathymetric data can also be useful in submerged structure inspections or bottom clearance in shallow waters performed mostly with the use of sonars [Felski et al., 2015]. Detection of $\mathrm{SBO}^{2}$ is essential for Mine Countermeasure Warfare, and sea bottom classification.

The use of precise positioning systems with centimetric horizontal accuracy finds its justification when performing verification of underwater targets with MBES. Gathering bathymetric data from multiples survey lines over objects requires repetitiveness and reliability of information. It is critical in defining correct attributes of the measured sea bottom object.

\section{REFERENCES}

[1] Ahmed I., Elhattab A. I., Recent positioning techniques for efficient port operations and development of Suez Canal corridor, MARLOG 5, 2016.

[2] Brissette M., Stop Using DGPS! The Unsuitability of Non-centimetric Positioning for Shallow-water MBES Surveys, 'Hydro International', 2012, No. 7(16).

[3] Howlett Ch., Stop Using DGPS!, [online], https://www.hydro-international.com/ content/article/stop-using-dgps-2 [access 03.06.2017].

[4] Felski A., Grządziel A., Wąż M., Experience with the use of a rigidly-mounted side-scan sonar in a harbour basin bottom investigation, 'Ocean Engineering', 2015, Vol. 109, pp. 439-443.

[5] Manual of hydrography, Publication C-13, Monaco 1st Edition, May 2005, Corrections February 2011.

[6] S-44 IHO Standards for Hydrographic Surveys, February 2008.

[7] Rogowski J., Specht C., Weintrit A., Evaluation of Positioning Functionality in ASG EUPOS for Hydrography and Off-Shore Navigation, 'TransNav', 2015, Vol. 9, No. 2, pp. 221-227.

${ }^{2} \mathrm{SBO}-$ Small Bottom Object: an object with a dimension less than $2 \mathrm{~m} \times 2 \mathrm{~m}$. 
Received October 2016

Reviewed July 2017

Published 26.09.2017

\section{DOMINIK IWEN}

Polish Navy

Karnkowskiego 3 Str., 81-202 Gdynia, Poland

e-mail: dominikiwen@wp.pl

\section{STRESZCZENIE}

Wysokorozdzielcze pomiary prowadzone echosondą wielowiązkową nie mogą być wykonywane w połączeniu z użyciem pozycjonowania opartego na systemie DGPS, zwłaszcza gdy priorytetem jest rozpoznanie cech obiektu. Wprawdzie specyfikacja IHO odnośnie pomiarów specjalnych dopuszcza błąd pozycji w płaszczyźnie horyzontu w granicach $2 \mathrm{~m}$, to należy być świadomym tego, że skutkuje to degradacją pomiarów prowadzonych echosondą, nominalnie gwarantujących centymetrowe dokładności. 